\title{
PRAKTIKALITAS MODUL FISIKA SMA BERBASIS MODEL PEMBELAJARAN GENERATIF PADA MATERI LISTRIK DINAMIS TERINTEGRASI KELISTRIKAN JANTUNG
}

\author{
Megasyani Anaperta \\ Staf Pengajar Prodi Fisika STKIP PGRI Sumatera Barat; \\ mega.syani@yahoo.com \\ http://dx.doi.org/10.22202/irfes.2015.v2i1.1788
}

\begin{abstract}
Practicalities of a learning is one's ability to be possessed by the teacher at any educational institution in order to develop the ability of students to solve problems they encounter every day. One of the tools that can support these objectives is the physics module using generative learning model in the material heart's electrical integrated dynamic power.

This type of research is the research and development using the model proposed by Plomp (2010) which consists of preliminary research, prototyping phase, and assessment phase. At this stage of the analysis pendefenisian curriculum, students analysis, and analysis of the concept. In the planning stage to design a module for physics. Furthermore, during the development stage to test the validity and practicalities.

The result showed that the modules use the generative learning model dynamically integrated electrical material heart's electrical practicality value based on observation sheets and questionnaires categorized practicality practical design can be seen from the test results obtained by the practicalities of the average percentage of enforceability of the RPP was $93.2 \%$, the mean average teacher questionnaire responses $90 \%$, and the average student questionnaire responses $91 \%$.
\end{abstract}

Keywords: The heart's electrical, generative learning model, learning modules physics

\begin{abstract}
ABSTRAK
Praktikalitas suatu pembelajaran merupakan salah satu kemampuan yang harus dimiliki oleh guru pada setiap satuan pendidikan agar dapat mengembangkan kemampuan peserta didik dalam memecahkan masalah yang mereka hadapi sehari-hari. Salah satu alat yang dapat mendukung tujuan tersebut adalah Modul fisika menggunakan model pembelajaran generatif pada materi listrik dinamis terintegrasi kelistrikan jantung.

Jenis penelitian yang digunakan adalah research and development menggunakan model yang dikemukakan oleh Plomp (2010) yang terdiri atas preliminary research, prototyping phase, dan assessment phase. Pada tahap pendefenisian dilakukan analisis kurikulum, analisis siswa, dan analisis konsep. Pada tahap perencanaan dilakukan perancangan modul untuk mata pelajaran fisika. Selanjutnya, pada tahap pengembangan dilakukan uji validitas dan praktikalitas.

Dari hasil penelitian diperoleh bahwa modul yang menggunakan model pembelajaran generatif pada materi listrik dinamis terintegrasi kelistrikan jantung Nilai kepraktisan berdasarkan lembar observasi dan angket kepraktisan rancangan dikategori praktis dapat dilihat dari hasil uji praktikalitas diperoleh persentase rata-rata keterlaksanaan RPP adalah 93,2\%, rata-rata angket respon guru 90\%, dan rata-rata angket respon siswa $91 \%$.
\end{abstract}

Kata kunci: kelistrikan jantung, model pembelajaran generatif, modul pembelajaran fisika

\section{PENDAHULUAN}

Tujuan pendidikan nasional tersebut diperlukan usaha yang sungguh-sungguh dalam penataan sistem pendidikan menyangkut penyempurnaan kurikulum. Kurikulum merupakan pedoman dalam pelaksanaan pembelajaran agar tercapai 
tujuan yang diharapkan. Oleh karena itu pemerintah terus berupaya mengembangkan kurikulum. Mulai dari kurikulum 1994, Kurikulum Berbasis Kompetensi (KBK), Kurikulum Tingkat Satuan Pendidikan (KTSP) sampai Kurikulum 2013 yang sudah diterapkan saat ini.

Kurikulum 2013 mencakup pengembangan kompetensi sikap, pengetahuan dan keterampilan. Pembelajan pada kurikulum 2013 menggunakan pendekatan saintifik, yaitu pembelajaran yang mendorong peserta didik lebih mampu dalam mengamati, menanya, mencoba/mengumpulkan data, mengasosiasi/menalar, dan mengomunikasikan. Materi pembelajaran dihubungkan dengan fakta atau fenomena yang terjadi dalam kehidupan sehari-hari. Proses pembelajaran berpusat pada peserta didik dan memungkinkan peserta didik untuk lebih aktif dalam proses pembelajaran.

Kenyataan yang ditemukan di lapangan, berdasarkan hasil pengamatan yang dilakukan di SMA Adabiah 2 Padang ditemui bahwa perangkat pembelajaran yang digunakan belum menyajikan aplikasi dari materi pembelajaran terhadap fakta atau fenomena yang terjadi dalam kehidupan sehari-hari. Hal ini dapat dilihat dari RPP yang digunakan oleh guru. Dalam RPP yang digunakan oleh guru belum tergambar kegiatan yang menghubungkan materi pembelajaran dengan fakta atau fenomena yang terjadi dalam kehidupan sehari-hari. Langkah-langkah dalam kegiatan pembelajaran merupakan langkahlangkah kegiatan pembelajaran konvensional, yaitu peserta didik diberikan konsep, rumus dan contoh soal, kemudian di akhir pembelajaran peserta didik diberikan latihan.

Permasalahan lain yang ditemukan juga terlihat pada bahan ajar yang digunakan. Guru hanya terpaku menggunakan buku teks saja. Guru mengajarkan materi pembelajaran sesuai dengan urutan yang ada dalam buku teks dan di akhir pembelajaran peserta didik diberikan latihan soal-soal yang diambil dari buku teks tersebut. Dalam bahan ajar yang digunakan guru tidak disajikan aplikasi atau contoh penerapan materi pembelajaran dalam kehidupan sehari-hari. Pada bahan ajar langsung disajikan konsep yang ringkas kemudian diberikan rumus, dan dilanjutkan dengan pemberian contoh soal. Padahal sebenarnya guru bisa membuat bahan ajar yang sesuai dengan kebutuhan peserta didik. Salah satu bahan ajar yang dapat dikembangkan oleh guru adalah Modul. Namun di SMA Adabiah 2 Padang masih kurang tersedia Modul yang dikembangkan oleh guru. Hal ini disebabkan oleh masih terbatasnya kemampuan guru untuk mengembangkan Modul. Oleh sebab itu, guru lebih memilih cara praktis dengan menggunakan Modul yang didapatkan dari penerbit yang datang ke sekolah-sekolah. Modul tersebut umumnya berisi rangkuman materi, rumus, contoh soal dan soal-soal latihan yang berupa pilihan ganda dan tes uraian. Dalam Modul juga tidak disajikan fenomena atau fakta yang ada dalam kehidupan sehari-hari yang berhubungan dengan materi pembelajaran, sehingga peserta didik tidak tahu apa aplikasi materi pembelajaran dalam kehidupan mereka sehari-hari.

Permasalahan di atas juga didukung dengan hasil belajar siswa peserta didik yang masih rendah. Rendahnya hasil belajar siswa peserta didik juga dipengaruhi oleh sikap siswa peserta didik selama proses pembelajaran. Peserta didik sering melakukan aktivitas-aktivitas yang kurang bermanfaat selama pembelajaran berlangsung, seperti disaat guru meminta peserta didik untuk berdiskusi dengan teman sebangkunya kebanyakan dari peserta didik hanya berbicara saja. Selain itu, sedikit sekali peserta didik yang mampu menghubungkan materi pembelajaran dengan fenomena atau fakta yang ada dalam kehidupan sehari-hari.

Untuk mengatasi permasalahan di atas, diperlukan suatu perangkat pembelajaran yang mendukung proses pembelajaran sehingga dapat memfasilitasi peserta didik untuk menghubungkan materi pembelajaran dengan fenomena yang terjadi dalam kehidupan sehari-hari. Perangkat pembelajaran juga dapat dikolaborasikan 
dengan model pembelajaran yang sesuai dengan karakter peserta didik untuk mencapai tujuan pembelajaran. Salah satu model pembelajaran yang cocok dengan hal diatas adalah model pembelajaran Generatif.

$\begin{array}{llr}\text { Model pembelajaran generatif } & \text { perta didik } \\ \text { menuntut untuk }\end{array}$ mengeksplorasi pengetahuan awalnya yang diperoleh dari pengalaman sehari-hari maupun dari pembelajaran pada tingkat sebelumnya, kemudian dihubungkan dengan pengetahuan baru tentang materi pembelajaran yang dipelajari. Model pembelajaran generatif terdiri dari 4 tahapan, yaitu tahap eksplorasi, tahap pemfokusan, tahap tantangan dan tahap aplikasi. Dengan tahap-tahap pembelajaran tersebut, peserta didik diharapkan memiliki pengetahuan, kemampuan serta keterampilan untuk mengkonstruksi atau membangun pengetahuan secara mandiri ( Wena, 2011).

Pembelajaran generatif dimulai dengan tahap eksplorasi, dimana peserta didik dituntut untuk mengekplorasi pengetahuan, ide atau konsep awal yang diperoleh dari pembelajaran pada tingkat kelas sebelumnya ataupun dari pengamatan terhadap fenomena yang terjadi dalam kehidupan sehari-hari. Selanjutnya tahap pemfokusan, peserta didik melakukan pengumpulan data yang diperoleh dari kegiatan pembelajaran ataupun kegiatan praktikum. Tahap tantangan, peserta didik memberikan pertimbangan ide kepada peserta didik lain, membandingkan ide masing-masing kemudian melaporkan kesimpulan yang didapat ke depan kelas, mengoreksi kesalahan pemahaman apabila ada peserta didik lain yang kesimpulannya kurang tepat. Tahap aplikasi, kegiatan peserta didik yaitu menyelesaikan masalah dengan menggunakan konsep dalam situasi baru. Dengan langkah-langkah tersebut peserta didik akan mampu untuk menghubungkan materi pembelajaran dengan fenomena yang terjadi dalam kehidupan sehari-hari, sesuai dengan tujuan pembelajaran fisika.

Fisika merupakan bagian dari sains yang mempelajari fenomena dan gejala alam secara empiris, logis, sistematis dan rasional yang melibatkan proses dan sikap ilmiah. Peserta didik dapat memahami konsep dan prinsip fisika dengan benar dalam proses pembelajaran dan menggunakannya dalam kehidupan seharihari. Salah satu materi dalam mata pelajaran fisika yaitu materi Listrik Dinamis. Listrik Dinamis sangat banyak aplikasinya dalam kehidupan sehari-hari. Salah satunya adalah aplikasi listrik pada jantung manusia.

Jantung merupakan organ yang sangat penting bagi manusia. Oleh karena itu perlu kesadaran yang tinggi untuk menjaga kesehatan jantung. Untuk menjaga jantung agar tetap sehat diperlukan pengetahuan yang lebih mengenai jantung, baik itu mengenai struktur, cara kerja dan hal-hal yang mengakibatkan terhambatnya kerja jantung. Jantung merupakan salah satu sumber energi listrik di dalam tubuh makhluk hidup. Mekanisme timbulnya listrik di dalam jantung sama halnya dengan kelistrikan, dimana arus listrik akan dihasilkan dalam sebuah rangkaian tertutup yang mempunyai perbedaan potensial. Gejala kelistrikan pada jantung telah lama diaplikasikan dalam bidang kedokteran. Listrik tersebut yang dapat menyebabkan jantung berdetak, bergerak memompakan darah ke seluruh tubuh mahkluk hidup. Terhambatnya aliran listrik pada jantung akan menyebabkan tidak lancarnya aliran darah ke seluruh tubuh. Inilah yang menyebabkan beberapa penyakit yang berkaitan dengan jantung.

Pada penelitian ini materi tentang kelistrikan jantung diintegrasikan pada materi listrik dinamis menggunakan model pembelajaran generatif. Diharapkan setelah proses pembelajaran, peserta didik dapat mengetahui betapa pentingnya jantung bagi tubuh, kemudian mereka dapat berpikir bagaimana menjaga jantungnya agar tetap sehat dan dapat berfungsi sebagaimana mestinya.

Berdasarkan uraian diatas, peneliti bermaksud mengembangkan perangkat pembelajaran Fisika SMA berbasis model pembelajaran generatif pada materi listrik dinamis terintegrasi kelistrikan jantung. 
Adapun perangkat pembelajaran yang dikembangkan mencakup Silabus, Rencana Pelaksanaan Pembelajaran (RPP) dan Modul.

\section{METODE PENELITIAN}

Jenis penelitian yang digunakan adalah penelitian pengembangan (research and development) menggunakan model yang dikemukakan oleh Plomp (2010) yang terdiri atas fase investigasi awal (preliminary research), fase perancangan, realisasi (prototyping phase) dan fase penilaian (assessment phase). Pada tahap pendefenisian dilakukan analisis kurikulum, analisis siswa, dan analisis konsep. Pada tahap perencanaan dilakukan perancangan modul untuk mata pelajaran fisika. Selanjutnya, pada tahap pengembangan dilakukan uji validitas dan praktikalitas. Data penelitian ini diperoleh melalui lembar validasi bahan ajar, angket praktikalitas dan lembar observasi. Penelitian ini digunakan untuk mengembangkan perangkat pembelajaran menggunakan model pembelajaran generetif pada materi Listrik Dinamis terintegrasi kelistrikan jantung kelas X SMA Semester 2. Perangkat yang akan dikembangkan adalah silabus, RPP, dan modul.

Jenis penelitian yang dilakukan adalah penelitian pengembangan. Menurut Sugiyono (2008) metode penelitian dan pengembangan adalah metode penelitian yang digunakan untuk menghasilkan produk tertentu, dan menguji kepraktisan. Selain itu Sunarto (2005:1) menyatakan penelitian pengembangan adalah upaya untuk mengembangkan dan menghasilkan suatu produk berupa materi, media, alat atau strategi pembelajaran. Model pengembangan perangkat pembelajaran ini menggunakan model pengembangan yang dikemukakan oleh Plomp (2010) yang terdiri dari fase investigasi awal (preliminary research), fase perancangan dan realisasi (prototyping phase), dan (3) fase penilaian (assessment phase).

Langkah-langkah rancangan pengembangan handout diatas dapat dirinci sebagai berikut :

a. Fase investigasi awal (preliminary research)
Pada fase ini peneliti melakukan analisis awal atau identifikasi masalah, analisis kebutuhan, analisis konsep atau isi materi, dan pengkajian literatur yang diperlukan dalam pembelajaran. Analisis konsep bertujuan untuk menentukan isi dan materi pembelajaran yang dibutuhkan dalam pengembangan handout. Pada analisis konsep, peneliti melakukan identifikasi terhadap konsep esensial dari materi Listrik Dinamis. Selanjutnya, dilakukan analisis terhadap karakteristik siswa untuk menentukan model pengembangan Perangkat Pembelajaran yang akan digunakan. Selain itu, peneliti juga melakukan kajian terhadap literatur yang tersedia.

\section{b. Fase Perancangan dan Realisasi (prototyping phase) \\ Pada fase ini dilakukan perumusan} atau perancangan terhadap handout. Rancangan handout ini merujuk pada panduan pengembangan bahan ajar yang dikeluarkan oleh Depdiknas. Perancangan bahan ajar meliputi beberapa tahapan, yaitu: (1) mengkaji kesesuaian materi dengan standar kompetensi dan kompetensi dasar yang terdapat dalam kurikulum, (2) menentukan kedalaman materi dan ruang lingkup Perangkat Pembelajaran, (3) menentukan urutan Perangkat Pembelajaran, (4) menentukan jenis perlakuan yang akan diberikan terhadap Perangkat Pembelajaran, (5) menentukan sumber materi pembelajaran. Pada tahapan ini, dilakukan penulisan, penelaahan dan pengeditan Perangkat Pembelajaran yang disusun. Perancangan Perangkat Pembelajaran dibuat sesuai dengan indikator yang ditetapkan dan berdasarkan format yang disesuaikan dengan kebutuhan peneliti.

Pada fase ini dilakukan formative evaluation yang meliputi self evaluation, expert reviews, one-to-one, dan small group, serta field test. Alur desain untuk formative evaluation ditunjukkan pada Gambar 1. 


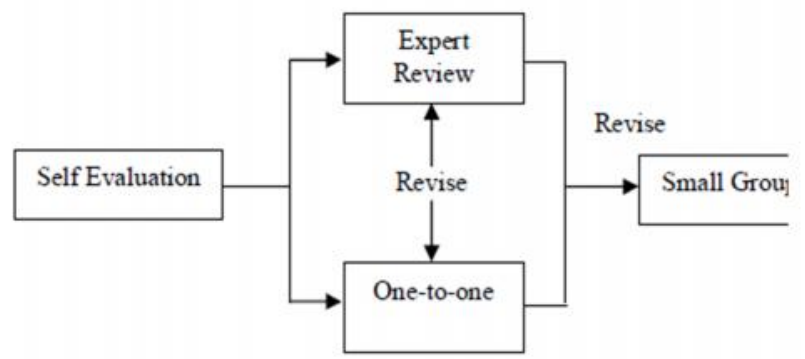

Gambar 1. Alur Desain Formative Evaluation (Tessmer : 1998)

\section{1) Self Evaluation}

Pada tahap ini dilakukan pendesainan handout yang akan dikembangkan. Pendesainan dilakukan berdasarkan hasil analisis awal atau identifikasi masalah, analisis kebutuhan dan analisis konsep atau isi materi, dan pengkajian literatur yang diperlukan dalam pembelajaran.

\section{2) Expert Review}

Pada tahap expert review, dilakukan penilaian dan evaluasi oleh pakar terhadap handout yang telah dirancang. Pakar-pakar tersebut menilai validasi isi, konstruk, dan bahasa. Saran-saran dari para pakar digunakan sebagai acuan untuk merevisi handout yang dikembangkan. Bagian utama yang divalidasi adalah kesesuaian KD, indikator, kebenaran konsep dan bahasa yang digunakan. Masukan dari validator digunakan untuk memperbaiki dan merevisi perangkat pembelajaran yang dikembangkan sehingga dihasilkan handout yang valid.

3) One-to-one
Pada tahap one-to-one, dilakukan uji coba desain yang telah dikembangkan kepada siswa dan dosen yang menjadi tester. Hasil dari uji coba ini digunakan untuk merevisi desain yang telah dibuat.

\section{4) Small group}

Hasil revisi dari telaah para ahli dan kesulitan yang dialami pada saat uji coba pada Uji coba pertama dijadikan dasar untuk merevisi perangkat pembelajaran tersebut, kemudian hasilnya diujicobakan pada small group. Hasil dari pelaksanaan ujicoba ini selanjutnya digunakan untuk revisi sebelum dilakukan ujicoba pada tahap field test. Setelah dilakukan revisi handout berdasarkan saran dan komentar siswa pada small group, diperoleh hasil analisis terhadap perangkat pembelajaran tersebut.

5) Field Test

Hasil revisi small group diujicobakan ke subjek penelitian. Uji coba ini merupakan uji lapangan atau field test. Perangkat pembelajaran yang telah diujicobakan pada uji lapangan adalah perangkat pembelajaran yang telah memenuhi kriteria kualitas yang meliputi validitas, kepraktisan Hasil analisis kurikulum dapat dilihat pada tabel 1.

$$
\text { Tabel 1. Hasil Analisis Tujuan Pembelajaran }
$$

\begin{tabular}{|l|l|}
\hline \multicolumn{1}{|c|}{ Aspek Kompetensi } & \multicolumn{1}{c|}{ Tujuan Pembelajaran } \\
\hline $\begin{array}{l}\text { Kompetensi sikap } \\
\text { spritual }\end{array}$ & $\begin{array}{l}\text { Menyadari fenomena kelistrikan jantung sebagai } \\
\text { ciptaan Tuhan }\end{array}$ \\
\hline Kompetensi sikap sosial & $\begin{array}{l}\text { Terlibat aktif dalam pembelajaran dan memunculkan } \\
\text { sikap kreatif, logis, rasa ingin tahu, analitis dalam } \\
\text { aktivitas sehari-hari-hari sebagai wujud implementasi } \\
\text { sikap dalam melakukan percobaan, melaporkan dan } \\
\text { berdiskusi and listrik }\end{array}$ \\
\hline Kompetensi pengetahuan & $\begin{array}{l}\text { 1. Siswa dapat menjelaskan konsep kuat arus listrik } \\
\text { 2. Siswa dapat menjelaskan konsep tegangan listrik } \\
\text { 3. Siswa dapat menjelaskan konsep hambatan listrik } \\
\text { 4. Siswa dapat menjelaskan besaran-besaran } \\
\text { kelistrikan jantung }\end{array}$ \\
& $\begin{array}{l}\text { 5. Siswa dapat menjelaskan cara pemasangan alat } \\
\text { ukur kuat arus listrik dan tegangan dalam }\end{array}$ \\
\hline
\end{tabular}




\begin{tabular}{|l|l|}
\hline Aspek Kompetensi & \multicolumn{1}{c|}{ Tujuan Pembelajaran } \\
\hline rangkaian. \\
6. Siswa dapat menjelaskan cara kerja alat ukur \\
kelistrikan jantung \\
7. Siswa dapat menjelaskan hukum Ohm \\
8. Siswa dapat menerapkan hukum Ohm dalam \\
pemecahan masalah \\
9. Siswa dapat menjelaskan hukum I kirchoff dan \\
hukum II kirchoff \\
10. Siswa dapat menerapkan hukum I kirchoff dan \\
hukum II kirchoff dalam pemecahan masalah \\
11. Siswa dapat mengaplikasikan hukum I kirchoff \\
pada kelistrikan jantung \\
12. Siswa dapat menjelaskan energi dan daya listrik \\
13. Siswa dapat menghitung energi dan daya listrik \\
yang terpakai oleh peralatan listrik \\
14. Siswa dapat menjelaskan perbedaan listrik AC dan \\
DC berdasarkan grafik osiloskop \\
15. Siswa dapat menjelaskan penerapan listrik AC dan \\
DC dalam kehidupan sehari-hari \\
16. Siswa dapat menentukan jenis listrik jantung \\
berdasarkan grafik elektrokardiogram
\end{tabular}

\section{HASIL DAN PEMBAHASAN}

Praktikalitas Modul Fisika SMA Berbasis Model Pembelajaran Generatif Pada Materi Listrik Statis Terintegrasi Kelistrikan Jantung menggunakan model pengembangan

\subsection{Validasi Perangkat Produk}

Pada kegiatan ini pakar diminta untuk menilai perangkat pembelajaran yang sudah dibuat. Penilaian mencakup isi, penyajian, dan bahasa. Dalam memvalidasi, validator diminta untuk memberikan penilaian dan pendapat terhadap 
Rencana Pelaksanaan Pembelajaran (RPP) dan Modul yang telah dirancang

Para validator akan memberikan pendapat untuk revisi media yang sudah dibuat. Validasi dikatakan selesai apabila validator sudah menyatakan bahwa RPP dan Modul sudah valid dan telah diujicobakan pada kelas X semester 2 SMA Adabiah 2.

Setelah perangkat pembelajaran dirancang maka tahap selanjutnya adalah melakukan pengujian apakah perangkat tersebut valid dan praktis digunakan dalam proses pembelajaran.

perangkat pembelajaran telah mengacu pada kategori valid sehingga

perangkat pembelajaran sudah layak untuk diujicobakan dan digunakan dalam pembelajaran pada materi Listrik Dinamis.

Berdasarkan rekapitulasi hasil validasi perangkat pembelajaran maka dilakukan pengelompokan aspekaspek penilaian pada masing-masing perangkat pembalajaran. Berikut ini dijelaskan pengelompokan aspek penilaian dan hasil validasi masingmasing perangkat pembelajaran.

\subsubsection{Validasi Rencana \\ Pelaksanaan Pembelajaran}

Validasi dilakukan setelah perangkat pembelajaran selesai dirancang. Untuk memvalidasi peneliti meminta kepada validator untuk memvalidasi perangkat pembelajaran yang telah dibuat. Hasil validasi menunjukkan bahwa Rencana Pelaksanaan Pembelajaran (RPP) yang telah dirancang dapat digunakan dengan melakukan revisi. RPP yang telah dirancang berkategori sangat valid. Semua komponen RPP yang dituntut dalam permendiknas tentang standar proses telah ada dalam rancangan RPP yang dibuat.

RPP yang telah dirancang berkategori sangat valid. Semua komponen RPP yang dituntut telah ada dalam rancangan RPP yang dibuat. Isi RPP yang dibuat sudah sangat baik. Beberapa indikator isi RPP memperoleh nilai diatas 93,2\% yang berkategori sangat valid. Indikator-indikator tersebut adalah perumusan tujuan pembelajaran, prinsip pemilihan materi, pemilihan pendekatan dan metode, penggunaan sumber belajar, jenis kegiatan pembelajaran, susunan langkahlangkah pembelajaran, pilihan caracara pengorganisasian siswa agar dapat berpartisipasi dalam proses pembelajaran, melaksanakan kegiatan pembelajaran sesuai dengan urutan yang logis, prosedur penilaian meliputi penilaian awal, penilaian tengah (proses), dan penilaian akhir dan penggunaan bahasa. Ini berarti indikator-indikator yang harus ada pada sebuah RPP sudah tepat sesuai dengan panduan pengembangan RPP dan pendekatan yang digunakan.

Secara umum RPP sudah sangat baik. Meskipun dikategorikan sangat valid namun RPP terlebih dahulu direvisi sesuai dengan saran validator. Setelah dilakukan revisi barulah RPP digunakan dalam proses pembelajaran.

\subsubsection{Validasi Modul}

Sebelum Modul digunakan, Modul divalidasi oleh validator yang kompoten. Validasi modul dilakukan untuk mengetahui apakah isi, penyajian dan penggunaan bahasanya sudah tepat.

Penilaian validator menunjukkan bahwa modul Model 
Pembelajaran Generatif. Di samping itu tampilan gambar, huruf dan pewarnaan juga menarik bagi pembaca. Penggunaan bahasa menurut penilaian validator juga sudah mengacu pada penggunaan Ejaan Yang Disempurnakan (EYD).

\section{KESIMPULAN}

1. Penelitian dan pengembangan menghasilkan perangkat pembelajaran, berupa Rencana Pelaksanaan Pembelajaran (RPP), Modul Fisika Sma Berbasis Model Pembelajaran Generatif Pada Materi Listrik Statis Terintegrasi Kelistrikan Jantung yang valid

2. Hasil tahap define juga diperoleh model pembelajaran yang digunakan adalah model pembelajaran generatif. Hasil tahap perancangan diperoleh instrumen validasi, media pembelajaran, format perangkat dan prototipe perangkat pembelajaran yang terdiri silabus, RPP, dan modul berbasis model pembelajaran generatif pada materi listrik dinamis yang diintegrasikan dengan materi kelistrikan jantung.

3. Berdasarkan data hasil belajar siswa dapat diambil kesimpulan bahwa Rencana Pelaksanaan Pembelajaran (RPP) dan Modul yang dihasilkan berkategori praktis.

\section{DAFTAR KEPUSTAKAAN}

A, Junaedi. 2000. Kumpulan Kuliah Fisika Kedokteran. Yogyakarta: FKUGM.

Arif, Khairul Anam. 2013. Penerapan Model

Pembelajaran Generatif untuk Meningkatkan Hasil Belajar Siswa Kelas XI SMA Islamic Centre Demak Tahun Ajaran 2013/2014. Semarang: IKIP PGRI.

Arikunto, Suharsimi. 2010. DasarDasar Evaluasi Pendidikan (Edisi Revisi). Jakarta: Bumi Aksara.

Aunurrahman. 2009. Belajar dan Pembelajaran. Bandung: Alfabeta.

Depdiknas. $2006 . \quad$ Standar Kompetensi Mata Pelajaran Fisika. Jakarta: Balitbang Depdiknas.

Depdiknas. 2007. Standar Proses untuk Satuan Pendidikan Dasar dan Menengah. Jakarta: BSNP.

Depdiknas. 2008. Pedoman Pengembangan Perangkat Pembelajaran KTSP. Jakarta: BSNP.

Fauzan, Ahmad. 2002. Laporan Penelitian Hibah Bersaing XII/I Perguruan Tinggi. Padang: UNP.

Hulukati, Evi. 2005. Mengembangkan Kemampuan Komunikasi dan Pemecahan Masalah Matematika Siswa SMP 
Melalui Model Pembelajaran Generatif. Disertasi tidak diterbitkan. Bandung: Program Pascasarjana UPI.

Hendri, Weria.2011. Kajian Pola Rekaman Elektrokardiogram untuk Mendeteksi Kelainan Jantung pada Manusia. Skripsi tidak diterbitkan. Padang: UNP.

Ifdil. 2011. Pelayanan E-Konseling (Pengolahan Hasil Pengadministrasian Alat Ungkap Masalah (AUM) dengan Menggunakan Program Aplikasi). Makalah disajikan pada Seminar Internasional Bimbingan dan Konseling dalam Rangka Kongres XI dan Konvensi Nasional XVI ABKIN Surabaya, $14 \quad-17$ November 2009.

Isaacs, Alan. 1995. Kamus Lengkap Fisika. Jakarta: Erlangga.

Kanginan, Marthen. 2006. Fisika untuk SMA kelas X. Jakarta: Erlangga.

Keren, Kinneret. 2011. Cell Motility: The Integrating Role of The Plasma Membrane. Israel: Israel Institute of Technology. Jurnal dari Departement of Physics, The Network Biology Research No. 40: 1013-1027.

Mulyatiningsih, Endang. 2012. Pengembangan Model Pembelajaran. www.staff.uny.ac.id (Diakses pada 12 Juni 2014).

Pannen, Paulina.2005. Konstruktifisme dalam pembelajaran. Jakarta: PAUPPA. Universitas Terbuka.

Permendiknas RI No. 41 Tahun 2007 Tentang Standar Proses. Jakarta: DPR RI.

Prayitno, dkk. 2011. Buku Panduan Penulisan Tesis dan Disertasi. Padang: Program Pascasarjana UNP.

Rochmad. 2012. Desain Model Pengembangan Perangkat Pembelajaran Matematika. Jurnal Kreano, ISSN : 20862334. Diterbitkan oleh Jurusan Matematika FMIPA UNNES Volume 3 Nomor 1, Juni 2012

Riduwan. 2009. Belajar Mudah Penelitian untuk Guru, Karyawan dan Peneliti Pemula. Bandung: Alfabeta.

Salinan Lampiran Permendikbud Nomor 65 Tahun 2013 tentang Standar Proses. Jakarta: BSNP.

Salinan Lampiran Permendikbud Nomor 66 Tahun 2013 tentang Standar Penilaian. Jakarta: BSNP.

Sanjaya, Wina. 2008. Strategi Pembelajaran Berorientasi Standar Proses Pendidikan. Jakarta: Kencana Prenada Media Group.

Sudjana, Nana. 2006. Penilaian Hasil Proses Belajar Mengajar. Bandung: Remaja Rosdakarya.

Supiyanto. 2007. FISIKA untuk SMA Kelas X. Jakarta: Phibeta Aneka Gama. 
Trianto. 2009. Mendesain Model

Pembelajaran Inovasi

Progresif. Jakarta: Kencana Prenada Media.

Trianto. 2010. Model Pembelajaran Terpadu. Jakarta: Bumi Aksara.

Undang-Undang Republik Indonesia No. 20 Tahun 2003 Tentang Standar Nasional Pendidikan. Jakarta: DPR RI dan Presiden RI.I

Wena, Made. 2011. Strategi Pembelajaran Inovatif Kontemporer. Jakarta Timur: Bumi Aksara.

Yulianti, Fitri dkk. 2011. Inovasi Tanpa Batas Fisika SMA/MA Kelas $X$. Yogyakarta: Kendi Mas Media. 